Весна Р. Крајишник

Универзитет у Београду

Филолошки факултет
371.3::811.163.41'243

https://doi.org/10.18485/melissa.2017.16.2.ch5

\title{
НЕКА ПИТАЊА ИЗ МЕТОДИКЕ НАСТАВЕ СРПСКОГ КАО СТРАНОГ ЈЕЗИКА ${ }^{1}$
}

\begin{abstract}
Сажетак
Већ дуги низ година методичка истраживања указују на специфичности наставе страног језика у односу на наставу матерњег језика. Те специфичности се огледају у методичким, дидактичким, глотодидактичким, али и ширим лингвистичким аспектима. И док се методици наставе страног језика у свијету придаје све већа пажња, у нашој земљи се тек последњих година бојажљиво указује на дистинкцију двију методика, специфичности једне у односу на другу и потребу за примјеном и унапређењем методике наставе српског као страног језика.

У овом раду ће се указати на неке моменте у организацији наставе српског као страног језика у српском и страном језичком окружењу, на типологију часа и, с тим у вези, на посебне карактеристике лекторског часа са организационог и структурног аспекта. У раду се не прејудицирају методичка рјешења него се само указује на неке могућности које су се искристалисала кроз дугогодишњи рад са страним студентима, а могу послужити као одговор на нека основна питања онима који се први пут сусрећу са овим видом наставе, како у земљи, тако и у иностранству.
\end{abstract}

Кључне ријечи: методика наставе страног језика, српски као страни језик, лекторски час, организација наставе

\section{1. Увод}

Концепт методике наставе страног језика², као системског скупа наставне праксе и учења језика, и трагања за методама које

1 Рад је објављен у зборнику Српски као страни језик у теорији и пракси III, Београд, 2016, стр. 7-26.

2 У последње вријеме је све чешће у употреби термин глотодидактика (Дурбаба, Вучо), али ће се за потребе овог рада користити термин методика наставе с обзиром на то да је предмет овог рада избор различитих приступа проблематици наставе српског као страног језика од стране наставника са циљем остваривања што бољих резултата у наставном процесу. 
дају најбоље резултате представљали су преокупацију наставника и стручњака примијењене лингвистике током читавог 20. вијека. Тражили су се одговори на разна структурна, садржајна, организациона, психолшка, когнитивна и многа друга питања везана, како за предавање и учење, тако и за повезивање теорије и праксе.

Друга половина 20. вијека у развоју методике често се дефинише као „Доба метода“, током које су дате бројне препоруке за учење језика. У Великој Британији је преовладала метода ситуативног учења језика, а паралелно с њом у САД се појавила аудио-лингвална метода. Из ових двију метода временом се развила комуникативна метода, а све друге методе учења језика нашле су се у њеној сијенци. Комуникативна метода је заснована на следећим принципима:

- ученици уче језик кроз његово коришћење у комуникацији,

- аутентична комуникација мора да буде циљ активности у учионици,

- флуентност говора је важна димензија комуникације,

- комуникација укључује интеграцију различитих језичких вјештина,

- учење је креативно конструисан процес који укључује провјере и грешке.

Ова метода наставе језика је развила и бројне варијетете, као што су природан приступ, кооперативно учење језика, настава заснована на садржају, настава заснована на задацима итд.

Комуникативна метода у учењу страних језика задржала се и до данашњих дана, а њени различити варијетети, карактеристике, приступи и циљеви дефинисани су у бројним радовима у области примијењене лингвистике и методике наставе страних језика (LarsenFreeman, 2000; Richards and Rodgers, 2001; Howat, 1984; Вучо, 2009; Дурбаба, 2011).

Данас се методици наставе страних језика приступа као равноправној научној дисциплини у оквиру шире области - примијењене лингвистике, која се бави основним питањима учења и наставе страних језика при чему се примењују објективни, научни методи и анализе, на основу научних критерија установљених достигнућима лингвистике, антроплогије, психологије, педагогије и других дисциплина (Вучо, 2009:15). 
За разлику од неких „великих“ језика који су се почели учити као страни (L2) када у нашим подручијима још није била развијена ни писменост, српски као страни језик се системски почео учити тек половином прошлог вијека, како у земљи, тако и у иностранству. Оснивају се прве школе за стране језике, а између осталог и за српски као страни језик, посебно у Београду, у којима се спроводе интензивни курсеви језика (Коларчев народни универзитет, Институт за стране језике итд.). Средином педесетих година прошлог вијека Република Србија, у склопу савезне државе, почиње да закључује споразуме о упућивању предавача на иностране универзитете, односно прихвату контрактуалних лектора страних језика на нашим универзитетима. Од 1976. године Министарство просвете (Завод за међународну научну, просветну, културну и техничку сарадњу) интензивно унапређује и шири изучавање српско(хрватско)г језика на иностраним факултетима. Од 1986. године почиње са радом и Центар за српски као страни језик на Филолошком факултету, за потребе обуке страних студената који желе да студирају на Београдском универзитету и прихвата страних студената славистике који су долазили на усавршавање језика у нашу земљу, чиме се учење српског као страног језика подиже на један виши и организованији ниво. Међутим, за све то вријеме у српским лингвистичким круговима није се препознавао значај методике српског као страног језика нити се указивало на њену дистинкцију у односу на методику српског као матерњег језика. Предавачи који су се бавили наставом српског као страног језика развијали су, свако за себе, свој метод рада, учили се на грешкама и „тајно“ се ослањали на уџбенике страних језика црпећи идеје, моделе и приступе језичкој материји, а у методичким анализама за наставу страних језика проналазили начине и поступке извођења наставе.

Уобличавањем комуникативних задатака и њиховим дефинисањем кроз конкретне вербалне и невербалне вјештине Савјет Европе је почетком деведестих година дефинисао Европски језички портфолио (приручник за наставнике, наставнике-менторе и наставнике на неком степену усавршавања), односно Заједнички европски оквир за живе језике: учење, настава, оијењивање, до сада најзначајнији покушај обликовања курикулума овог типа. 
Полазећиодпремиседаучење странихјезикатокомшколовања нема за циљь коначни производ (који би претпостављао потпуно познавање страног језика), већ се оно схвата као стварање основе за даље учење и усавршавање (које би уповољним околностима могло или требало да буде доживотна активност), ЗЕО представља покушај да се детаљно опише језички учинак на одређеном нивоу; на основу тога би и појединци и институције могли имати тачан увид у језичка постигнућа и остварене компетенције (нпр. у циљу настављања учења језика). Пошто не представља опис ниједног појединачног језика, већ искључиво способности појединца да обави најразноврсније језичке делатности, он омогућава максималну упоредивост нивоа компетенције у различитим језицима. ЗЕО, наиме, обухвата скалу са шест нивоа компетенције подељених у три ступња: елементарно коришћење језика (A1 и A2), самостално коришћење језика (Б1 и Б2), компетентно коришћење језика (Ц1 и Ц2)(Дурбаба 2011:136).

Преводом овог документа на српски језик 2003. године он почиње да се примјењује у дефинисању језичких вјештина у наставнонаучним институцијама (за стране језике), а од 2004. године Центар за српски као страни језик на Филолошком факултету у Београду усклађује свој програм према шест наставних нивоа на основу препорука Заједничког европског оквира. Ово представља прву дефинисану и системску активност у нашој земљи којој је циљ приступ српском језику као страном. У вези са тим, дефинишу се језичке вјештине и језичке компетенције за сваку од њих, а за потребе њиховог савладавања развијају се и нове наставне методе, што, на неки начин, преставља почетак развоја методике наставе српског као страног језика. Развоју функционалног приступа настави српског као страног језика у оквиру примијењене лингвистике значајно доприносе два Зборника радова (Српски као страни језик у теорији и пракси I, 2007. и Српски као страни језик у теорији и пракси II, 2011) у којима су приказани радови са научних конференција посвећених изучаавању српског као страног језика у земљи и свијету, а који представљају својеврсне методичке приручнике за све који се баве овом врстом наставе. 
У складу са новим тенденцијама у проучавању стратегија учења, методика уопште, а посебно методика страних језика, последњих година добија све већи значај у модерном образовном процесу. Ослушкујући потребе за дефинисањем и образовањем новог профила наставника који би на компетентан и савремен начин био у стању да страним студентима пренесе језичке и културолошке садржаје свог матерњег језика, Филолошки факултет је покренуо и мастер програм Српски као страни језик, дајући примат функционалној употреби језика и методици наставе српског као страног језика.

\section{2. Општеметодичке особености наставе српског као страног језика}

Свако ко се нађе у ситуацији да предаје страни (L2) језик, па тако и српски као страни, суочиће се са безброј питања у вези са организацијом и реализацијом наставе, поготово у ситуацији када је потребно самостално организовати и програмски дефинисати наставу:

- Који је тип наставе изабрати?

- Који тип часа примијенити и у складу са тим које методе изабрати?

- Каква је најпродуктивнија атмосфера на часу и како мотивисати студенте?

- Како изабрати наставни материјал?

- Како се врши процјена знања?

- Колико треба да траје час и колики број часова је оптималан за савладавање одговарајућег нивоа знања?

- Који је број студената оптималан у једној наставној групи и какав је састав студената с обзиром на језичко (пред)знање и матерњи језик?

Свим овим питањима, али и многим другим, кључним за структуру наставног процеса и организацију наставе страног језика, баве се многе комплементарне научне дисциплине-педагогија, психологија, лингвистика, културологија, социологија, антроплогија, дидактика, а све оне заједно, кроз своје области истраживања обједињене су у глотодидактику, односно методику наставе страног језика. 


\section{1. Облик наставе}

Од кад у људској цивилизацији постоји језик као средство комуникације и развијена свијест о различитим културама и различитим језицима, постојала је потреба да се успостави међукултурална комуникација преко језика. Међутим, тек са развојем школског система почео је и развој метода и техника за наставу и учење страног (другог, трећег, четвртог итд.) језика.

Институционализована настава страних језика (класичних и живих) постоји практично од самог настанка школског система у модерном смислу речи (у највећем броју европских земаља најмање два века) (Дурбаба 2011:11).

Дуго је школски систем познавао само један облик наставе учионички, in vivo, у коме су биле јасно дефинисане и ограничене улоге наставника и ученика. Настава страног језика у учионици пролазила је различите фазе током којих су се постепено помијерале улоге наставника и ученика, као главних судионика - од потпуне доминације наставника и апсолутне пасивизације ученика до активне интеракције и доминације ученика у складу са савременим захтјевима глотодидактике. Настава у учионици ствара услове за стални контакт између предавача и студента, као и међу студентима, што омогућава правовремену реакцију од стране предавача и перманентни увид у степен разумијевања и напредовања.

За разлику од учионичког типа наставе гдје одређена група студената учи са једним или више предавача, индивидуална настава претпоставља једног предавача и једног студента. Предност овог типа наставе огледа се у томе што темпо рада зависи искључиво од рецептивно-перцептивних способности студента, пажња предавача је усмјерена искључиво на језичке потребе једног студента, што обезбјеђује услове за брже напредовање. Са друге стране, недостатак овог типа часа је изостанак шире комуникације и живље атмосфере коју обезбјеђује група у учионици, као и самопозиционирање студента у односу на друге студенте.

Развојем информационих технологија крајем прошлог вијека, наставне активности почињу да се одвијају у „паметним“ учиони- 
цама, а настава се организује и „на даљину“. Сви популарни језици данас могу се учити онлајн, а међу њима и велии број „малих“ језика. Српски као страни језик први пут су представили преко електронске платформе аутори са Филозофског факултета у Новом Саду, који су свој уџбенички материјал прилагодили систему учења на даљину. Убрзо и Центар за српски као страни језик на Филолошком факултету у Београду покреће онлајн наставу српског као страног језика постављајући на moodle платформу посебно припремљен материјал.

Онлајн учење страних језика је у последње вријеме постало врло атрактивно, прије свега због практичних разлога: може се самостално учити било који језик, у било којој земљи, у било које вријеме и у условима који су најудобнији за студента, под условом да има одговарајуће техничке могућности. Поред тога, овај вид наставе омогућава и сталну самоеевалуацију о напретку у усвајању језика, као и прилично неограничен број покушаја рјешавања језичких задатака. Међутим, искуства са овом врстом наставе показују да она не може у сваком случају замијенити наставу у учионици, нити је увијек могуће постићи исте или боље резултате у односу на класичан вид наставе. На основу стеченог искуства, али и увидом у резултате овог облика наставе за друге језике, уочавају се неки знатни недостаци у односу на класичну учионицу: неусклађеност временских зона приликом консултација са предавачима (скајп) или разговор са другима кандидатима (чет), кратко вријеме консултација „уживо“ које ова платформа омогућава, немогућност предвиђања свих одговора на одређене језичке захтјеве (поготово у процјени слободне продукције) што намеће потребу строго дефинисаних захтјева чији се одговори могу предвидјети, а то као последицу има ограничавање употребе језичких садржаја у свим областима, посебно на вишим нивоима знања. Као највећи недостатак онлајн наставе свакако је недостатак живе интеракције који је један од најбитнијих услова за развијање вербалне продукције (Крајишник-Ломпар 2015).

\section{2. Тип часа и методе}

Увидом у типологију часа како је одређују дидактичари уочавамо неколико реализација, које се односе на наставу уопште: 
- интродуктивни тип - увођење у нова знања и нове технике;

- информативни тип - систематско информисање о битним елементима наставног рада

- експликативнитип-карактеристични елементи објашњавања

- демонстративни тип - демонстрација радних операција и наставних садржаја

- репродуктивни тип - понављање и вјежбање знања и вјештина

- креативни тип - развој креативних (мисаоних и когнитивних) способности

- корективни тип - корективне интервенције у наставном раду

- верификативни тип - систем вредновања знања и вјештина

- апликативни тип - примјена знања и способности (Продановић, Ничковић 1974:234)

Без обзира на то што ова типологија није намијењена само настави страног језика, лако је уочити да се она може примијенити и у глотодидактици. Основни тип часа у настави страног језика је лекторски час који подразумијева комбинацију свих типова часа како се детерминишу у дидактици. Час је интерактивни однос између наставника, ученика, наставних садржаја и дидактичко-технолошких окружења (Вилотијевић 1999:106) и управо стална интерактивност, у писменом и вербалном облику чини основну карактеристику лекторског часа. Како би се боље схватила комплексност овог типа часа, указаћемо на неке од његових најважнијих карактеристика и методе које их подржавају:

2.2.1. Акција, реакција и интеракција - предавач побуђује интересовање студената указивањем на језички проблем који може да буде фонетске, граматичке, лексичке или стилске природе, у зависности од тога какву реакцију жели од студен(а)та. Уколико је импут добро осмишљен, реакција од стране студен(а)та неће изостати, а улога наставника јесте да је прихвати, уколико је тачна, или коригује, уколико има потребе. Нпр. импут може да буде слика, системски постављена одређена граматичка законитост или компаративно дат примјер два стилска рјешења. Реакција ће бити лексичка реализација задатог семантичког садржаја (слика), уочавање и дефинисање граматичког правила или одређивање адекватног стилског рјешења. Након 
одговарајуће реакције могуће је развити интеракцију између наставника и студен(а)та проширујући или увјежбавајући одговарајући језички садржај. Бројне су методе које се примјењују у овом процесу и зависе од врсте језичког садржаја, али и од инвентивности и склоности предавача: вербално-текстуална, илустративно-демонстративна (гест, разне врсте илустрација, постери, стрипови, цртежи), аудиовизуелна (посебно значајна приликом указивања на дистинкцију у артикулацији и графији гласовног или акценатског система) итд.

2.2.2. Повезивање ситуација - у оквиру интеракције пожељно је студента што више активирати на начин да му се постављају питања у вези са задатом тематском или граматичком јединицом која се обрађује или утврђује. Без обзира на то о којој врсти језичке материје се ради, најбоља реакција студента се постиже персонализовањем ситуације. Нпр. тематска јединица - Здравље, граматичка јединица - перфекат: током или након објашњавања лексичог и граматичког слоја у лекцији студенту А се постави питање: „Да ли ти волиш да идеш код доктора?“ Очекиван је негативан одговор, мада ни позитиван неће пореметити концепцију развијања и повезивања ситуације. За студента је следеће питање предавача: „Зашто?“ неочекивано, јер се подразумијева да одлазак код доктора изазива код свих слична, негативна осјећања. Студент се труди да уобличи свој одговор, а он је најчешће: „Плашим се.“ Предавач укључује и друге студенте тако што пита студента А да ли се и студент Б плаши да иде код доктора. Студент А очекивано не зна, а предавач од њега тражи да постави питање студенту Б. Његов одговор треба да пренесе предавачу. На овај начин је могуће укљућити све студенте у учионици, али и повезати ову конструкцију са следећом: „Чега се још плашиш?“ (Чега се бојиш?, Од чега те је страх?). Ови модели су прилично тешки за студенте јер овакве конструкције нису синтаксички еквивалентне у већини индоевропских језика. Питање може да се односи на сваког студента појединачно. Овај начин повезивања је изузетно користан јер активира све студенте, принуђени су да слушају свако питање предавача и сваки одговор студената зато што не знају какво питање ће они добити, а при томе могу да искористе неки одговор који чују за свој одговор. На вишим нивоима знања врло захтјевне теме за 
проширење језичких садржаја и њихову вербализацију су политика, религија, међуљудски односи итд. Резултат је активно учешће свих на часу, повезивање тематских и граматичких јединица са личним искуством, меморисање и разумијевање реченичног модела, учење нових ријечи кроз забавну и продуктивну атмосферу на часу.

2.2.3. Импровизација - подразумијева реакцију предавача ad hoc, која је врло честа, упркос доброј припреми часа. С обзиром на врсту наставе, немогуће је предвидјети апсолутно позитивну реакцију студената на све што се обрађује, нити је могуће претпоставити колико ће студенти бити мотивисани да учествују у интеракцији. Често се дешава да се „проблем“ јави потпуно неочекивано (у сваком од језичких садржаја) и да поремети замишљени план. Улога предавача је да прати, иницира и адекватно реагује у складу са затеченим стањем у учионици, те да у врло флексибилним оквирима усмјерава даљи ток часа.

2.2.4. Научено одмах примијенити - ова премиса произилази из чињенице да страни студент треба да проговори на српском језику: да се идентификује, да искаже своје потребе, намјере, осјећања, да именује људе и предмете из свог окружења и домена интересовања, да разумије саговорника и информације којима је изложен, да изнесе и заступа свој став о битним темама итд. Да би се то постигло у релативно кратком времену и често у ограниченим условима (у ситуацијама када студент ван учионице није изложен српском језику), предавач мора да води рачуна о избору сваке лексичке јединице и сваке граматичке појаве у језику. Изабрани садржаји морају да буду функционални, примјенљиви чим се напусти учионица - на улици, у хотелу, на послу, на факултету, у студентском дому, на пијаци, у болници итд. Потребно је имати у виду да меморијски капацитети студента нису неограничени и да их треба попуњавати потребним и продуктивним језичким садржајима.

2.2.5. Ништа се не подразумијева - оно што је говорнику матерњег језика сасвим природно и о чему не размишља док говори или пише, страном студенту може да буде потпуно непознато и да изазове праву конфузију. Такви проблеми се јављају у дистинкцији артикулације фрикатива и африката, акценатском систему у падежној 
парадигми, гласовним промјенама, синтагмама са бројевима, разликовању, творби и употреби глаголског вида, реду ријечи у реченици у вези са енклитичким облицима, употреби замјеничких енклитичких облика итд. Ове појаве у језику свакако не треба избјегавати јер су оне саставни дио нашег стандардног језика, али их треба имати у виду приликом планирања часа и активности на часу и приступити им као језичком проблему који треба ријешити, најбоље на системском плану, дедуктивном методом како би се постигла што активнија улога студената.

2.2.6. Превести или објаснити - дилема која врло често мучи све који се нађу у ситуацији да предају страни језик. Лакше је превести, уколико постоји заједнички језик студената и предавача, али су ефекти памћења знатно слабији. Студенту се постављају сви садржаји у готовом облику, он треба да меморише и продукује. Све прилично личи на ех cathedra наставу. У другом случају, када се проналазе начини да се објасни непозната појава у језику или ријеч, студенти су максимално активни да повежу оно на шта предавач указује, помажу му приликом објашњавања и заједнички долазе до рјешења. Поред тога, студент не само да дугорочније памти нови садржај, него памти и ситуацију у којој је он објашњен. Ово је један од момената у настави језика када је инвентивност предавача непроцјенљива: нацртати, показати, одглумити, гестикулирати, све су то елементи који од предавача прави „чаробњака“. Наравно, постоје и садржаји које је тешко објаснити наведеним методама и функционалније и ефикаснје их је превести, али у сваком случају треба искористити сваку ситуацију која може утицати на динамичност часа и активност студената.

2.2.7. Стална евалуација - с обзиром на то да учење језика представља комплексан процес заснован на аналитичком, синтетичком и меморијском нивоу, неопходно је добро селектовати и умјерено дозирати нове садржаје, што је обично детерминисано програмом и уџбеником, али је улога предавача утоку припреме и реализације часа од битне важности. Након усвојене правилности (изговора, системске појаве или граматичког правила) и аналитичког повезивања са еквивалентом у матерњем језику (што студентима умногоме олакшава усвајање и употребу новог језика), потребно је тај језички сегмент 
активирати на тај начин што ће се омогућити да га студент употријеби (вербално) у што већем броју ситуација или говорних модела, што омогућава предавачу да уради прву евалуацију новостеченог знање студента. Процјене знања је потребно вршити континуирано, кроз различите облике употребе језика, не занемарујући ниједну језичку вјештину. За ове потребе добре резултате даје вербално-текстуална метода (развијање ситуативних модела, самостална вербална или писмена продукција, тест итд.).

Ово су само неке од карактеристика лекторског часа које га чине другачијим и често захтјевнијим од било ког другог типа часа. Наравно да овим нису исцрпљени сви задаци предавача, него је само указано на комплексност и одговорност посла који, уколико се ради са довољно знања, енергије и маште, врло брзо доводи до очекиваних резултата.

\section{3. Мотивација студената и атмосфера на часу}

Мотиви за учење језика могу бити различити: школовање, потребе на послу илиуслов задобијање посла, приватни, потреба за интеграцијом у новој животној средини итд. Врло често је један студент мотивисан на неколико начина да учи нови језик. Када је у питању српски као страни језик, најчешће га уче студенти који су на универзитетској размјени једно вријеме на нашем Универзитету и користе прилику, или им је то дио програма, да похађају наставу српског језика, и људи који се ради својих приватних потреба налазе у нашој земљи и језик им је потребан за језичку интеграцију у новој средини.

Међутим, за разлику од иницијалног, покретачког мотива за учење језика, који се у општој психологији учења назива секундарна мотивација, примарна мотивација студента углавном зависи од његових очекивања, задовољства у учењу, могућности уклапања у нову средину, тежине градива које учи итд. Мотивација је, поред опитих и парцијалних способности, један од најзначајнијих психолошких фактора постизањ а успеха у учењу. То је стање у коме индивидуа поседује неку врсту унутрашње снаге или порива који подстиче, регулише и усмерава учење. Та практичка снага омогућиће ученику да покрене или започне делатност учења, да управља оби- 
мом (ширином, екстензитетом) и степеном (дубином, интензитетом) учења и да осигура да учење потраје извесно (жељено, планирано) време (Кончаревић 2004:67).

На развој примарне мотивације, међутим, може да се утиче током наставног процеса, а најважнију улогу у томе свакако има предавач. Побуђивање мотивације да се савлада захтјевна материја као што је страни језик није лак задатак. Сви смо током процеса школовања имали искуства са „досадним“ и „занимљивим“ предметима, а често смо на основу тога стицали и професионална опредјељења за читав живот. Шта је то што један предмет, једну материју чини интересантном? Ако се искључе урођени афинитети за једну врсту знања, претпоставка је да свако ново знање које се стиче може бити занимљиво за учење уколико се презентује на довољно инвентиван и инспиришући начин. Настава страног језика је можда најзахвалнији примјер за то јер пружа прегршт начина, техника и модела којима се студенти (без обзира на узраст) могу мотивисати до те мјере да се радују одласку на час, активно учествују на њему и улажу додатни напор да савладају предвиђене садржаје. У учионичком типу часа, предавач је реализатор свих метода и захваљујући њему сваки језички садржај може да се креира у духу добре атмосфере и плодне подлоге за стицање нових знања. Али, исто тако, не постоји довољно добра метода ни довољно добар инструмент које немотивисан и недовољно стручан предавач не може упропастити.

\section{4. Избор наставног материјала}

Избор наставног материјала је условљен избором методе којом се представља језички садржај. Основна наставна средства која подржавају вербално-текстуалну методу су уџбеници и приручници. Уџбеник и приручник се појављују на истом нивоу, иако је ријеч о различитим стварима, јер њихов садржај није исти, нити се обликују на исти начин и са истом намјеном. Уџбеник је књига из које се учи и учи како се учи, што даје посебну одговорност ауторима уџбеника. Уџбенички корпус је, без обзира на то што је намијењен учењу страног језика, припадајући дио научног интересовања и васпитно-образовног процеса. Садржај приручника је методички. Заснован је на 
теорији и пракси проучавања и намијењен је искључиво студентима. Његов значај се огледа у подршци уџбеничке грађе, посебно оних области које су теже за усвајање.

На жалост, у настави српског као страног језика, за разлику од многих других језика, који нису нужно већи и значајнији од нашег, још увијек постоји проблем са недовољним бројем и неодговарајућим квалитетом уџбеника, а поготово приручника, који не задовољавају препоручене курикуларне услове од стране Европске заједнице. Поред тога, сви остали текстуални материјали су препуштени иновационим, стручним и маштовитим дјелатностима предавача, који, у зависности од нивоа знања студената, припремају, одабирају и представљају различите облике текстова у циљу обраде одговарајуће грађе.

На вишим нивоима знања језика драгоцијен текстуални материјал су новински чланци. Ово је студентима омиљено штиво, јер, са једне стране одражава актуелну ситуацију, чији су основни догађаји студентима углавном познати (политика, економија, спорт, култура, огласи, рекламе итд.), а са друге стране оживотворује пасивно знање језика. Задатак који им се овим поставља је исказивање релативно познатог садржаја на језику који уче, слиједећи језичка правила и већ научене садржаје. Добро припремљен час на коме се обрађује новински текст омогућава обраду разних врста граматичке и лексичке материје, као што су глаголски облици, творба ријечи, конструкција реченице, нова лексика итд.

Сличну вриједност имају и прилагођени књижевни текстови, чија је вриједност, поред језичке и социокултуролошка. Неопходно је овакав текст прилагодити нивоу знања студената и циљу који се жели постићи његовом обрадом.

Међу статичким наставним средствима илустративно-демонстративне методе најчешће се користе цртежи, фотографије, разни предмети, стрип и филм. Врло зхвално средство - цртеж или фотографија омогућава студенту сагледавање значења или ситуације, што утиче на његову сигурност у разумијевању теме на којој се ради. Са друге стране, предавач, ослобођен потребе да објашњава непознате ријечи или ситуацију, на много бржи и ефикаснији начин обрађује материју којој је цртеж или фотографија средство. Супрот- 
но овоме, велику активност студената подстиче и захтјев предавача да се нацрта задата тема, а све у циљу максималне активности у праћењу наставе.

Употреба стрипа као наставног средства подразумијева нешто виши ниво владања језика, да би студент могао да објасни ситуације које слиједе једна за другом, али и обрте ситуација (одличан начин увјежбавања зависних реченица). Дакле, стрип је средство које предвиђа ток радње и активности унутар ње, али и поред тога оставља студенту довољно простора за његову инвентивност у исказивању садржаја. Добро сачињен стрип има предности и за предавача и за студенте. Предавач је у овом случају слушалац, који само иступа у случају корекције исказа. Студент влада ситуацијом и у њој учествује и као аутор и као коректор других радова.

Филм је најкомплексније и најзахтјевније средство илустративно-демонстративне методе, које подразумијева довољно добро познавање језика који се учи. Филм представља садржај који омогућава пуну аудиовизуелну комуникацију и као такав захтијева од студента да прима и визуелни (што је лакше) и звучни, тј, језички садржај (што је теже). Разумијевање филма се провјерава препричавањем филма или дијалошком формом, при чему и једно и друго захтијевају активну присутност студента током презентације филма и његово учешће у накнадним језичким активностима.

Лабораторијско-експериментална метода у учењу језика подразумијева употребу лабораторије, посебно опремљене за извођење ове врсте наставе. Основни циљ који се постиже овом методом је правилност употребе одговарајућег сегмента или више њих унутар језичког корпуса. У зависности од концепције рада и избора језичког материјала, лабораторијски услови су идеални за овладавање фонетским законитостима у језику (правилан изговор изолованих гласова, ријечи, синтагми, препознавање акцента и његове дистинктивне вриједности), препознавање и разумијевање текста, увјежбавање и употреба лексике итд. Лабораторијска техника као наставно средство омогућава студенту да, без нелагодности (јер чује само себе и предавача) активно и самостално учествује у свим захтјевима који му се намећу, а при томе у исто вријеме подлијеже самокорекцији и корекцији од стране предавача (Крајишник 2008). 


\section{5. Процјена знања}

Учење страних језика неминовно укључује и компоненту тестирања, односно провере знања. У најопитијем смислу, тестирање, испитивање, евалуација и оцењивање представљају поступке за утврђивање и анализу знања, умећа и способности (Дурбаба 2011).

Сваки предавач бира начин и вријемеза процијену напредовање и постигнућа ученика. С обзиром на вријеме извођења провјера знања Кончаревић наводи иницијалну, финалну, етапну и текућу контролу (Кончаревић 2004), на основу којих је могуће установити ток напредовања студента, од почетка учења језика до завршетка одређеног циклуса предвиђеног планом и програмом. Иницијална провјера знања је потребна код студената који имају одговарајуће предзнање. На основу постигнутих резултата иницијалног тестирања предавач дефинише наставне групе и дефинише програм рада. Етапна и текућа контрола омогућавају, како предавачу, тако и студентима, увид у ток процеса усвајања језика, али и сигнал за евентуалне корекције у стратегији предавања или учења језика. Финална провјера даје кумулативни резултат усвајања језика након одређеног временског и програмског периода.

Динамика провјере знања зависи од става и потребе предавача да увиди и процијени степен овладавања одговарајућег сегмента језичког садржаја од стране студента, али и ефекте примјене одговарајућих метода и стратегија у наставном процесу. Са друге стране, студентима омогућава сагледавање личног напретка и евентуалне недостатке у познавању одређених језичких сегмената.

С обзиром на врсту процјене знања, оно се обично дијели на писмену и усмену, при чему се основне четири језичке вјештине - читање, писање, слушање и говор не могу ефикасно провјерити само једним начином. Писмена провјера знања је погодна за процјену слушања (разумијевање текста који се слуша), читања (разумијевање текста који се чита) и писања (граматичка и лексичка компетенција), док се говор као врста језичке компетенције која подразумијева вербалну реакцију на примљену информацију процјењује усменом провјером. 


\section{6. Час као јединица времена}

Колико треба да траје један час? Не постоји јединствно правило о дужини трајања часа. У различитим државама, па чак и у различитим административним јединицама исте државе постоје различита правила о дужини трајања школског часа. На нивоу универзитетске наставе такође постоје различита рјешења. На временско дефинисање часа утичу многи аспекти: психолошки (узраст и у складу са тим когнитивне способности и психичка зрелост ученика/студената), педагошки (ефикасност у коришћењу времена), методички (начин реализације програмског садржаја), организациони (организација просторних капацитета и дидактичких средстава) итд. Час је интерактивни однос између наставника, ученика, наставних садржаја и дидактичко-технолошких окружења који се, по правилу, остварује у временском трајању од 45 минута (Вилотијевић, 1999:106).

За одрасле полазнике - студенте настава се углавном организује у блоковима од једног сата, два школска часа, рјеђе три или више. Оваква концепција омогућава одраслим полазницима да, у складу са својим когнитивним способностима, прате наставне садржаје довољно концентрисано, а предавачу да, у оквиру ширег временског оквира, испредаје заокружену тематску и(ли) граматичку јединицу користећи се различитим методама и поступцима и облицима рада.

Колико часова је потребно? Ни на ово питање не постоји прецизно одређен одговор. Број часова прије свега зависи од језичког поријекла студен(а)та (знатно мањи број часова је потребан за студенте из сродне језичке породице), начина на који се учи језик (индивидуални, самостални, у оквиру курса, у оквиру студијског програма), циља који је потребно остварити (овладавање одговарајућим нивоом знања), времена за које је потребно реализовати циљ, као и од наставног планирања унутар наставне институције (дистрибуција језичког садржаја током трајања образовног процеса).

У Центру за српски као страни језик организује се блоковска настава од по три школска часа дневно, при чему седмично оптерећење зависи од нивоа знања студената. За студенте који немају никакво предзнање и треба да у току два семестра и укупно 450 часо- 
ва овладају основним знањима из свих језичких области (фонетика, фонологија, морфологија, синтакса и лексика) до нивоа А2, у циљу постизања континуитета потребног за продуктивно усвајање језика, настава се организује свакодневно у трајању од по три школска часа (један блок). За студенте са одговарајућим предзнањем, настава је конципирана четири пута седмично по један блок, док за студенте са вишим нивоом знања наставна динамика се смањује на три пута по један блок, јер је таквим студентима потребно да овладају одређеним сегментима у језику, за шта није нужан строг временски континуитет.

На основу искуства запослених у Центру (са одраслим полазницима) најбољи резултати се постижу током тзв, интензивне наставе: свакодневна настава у трајању од по три или четири школска часа. Свјесни смо да овакву наставу није увијек могуће организовати, поготово када је она дио универзитетског наставног програма и када укупан број часова чине и часови других наставних предмета. Ефекат овакве наставе се, наравно, појачава уколико се она одвија у природној говорној средини.

Међутим, број часова није нужно пропорционалан постигнутим резултатима. Искуство нам показује да настава од по шест или више часова дневно ${ }^{3}$ није у цјелини продуктивна, обиман језички материјал који предвиђа овако велики број часова није могуће меморисати темпом коју диктирају часови, те студенти, упркос теоријском знању језичког система, нису у стању да вербализују језичка знања на задовољавајући начин.

У жељи да добијемо јаснију слику о томе колики број часова је оптималан за продуктивно учење језика, за потребе овог рада спровели смо истраживање међу студентима који у Центру уче српски језик. Њихови одговори су били прилично очекивани:

3 Од 2010. до 2015. године запослени у Центру за српски као страни језик изводили су наставу српског језика страним студентима, стипендистима Владе Републике Србије. У оквиру пројеката Свет у Србији и Србија за Србе из региона студенти су учили српски језик са укупним фондом од 960 часова у трајању од осам мјесеци. Циљ је био да овладају нивоом знања Б1 како би могли наставити студије на српском језику на неком од факултета Београдског универзитета. Међутим, само једна трећина ових студената је успијевала да овлада предвићеним нивоом, док је највећи број њих успио да достигне ниво A2. На постигнуте резултате, поред времена проведеног у учењу, умногоме је утицао и матерњи језик студената (сличност са језичком структуром српског језика или њеним појединачним сегментима), као и мотивација и укупна зрелост студената да се суоче са различитим врстама изазова у новој средини. 


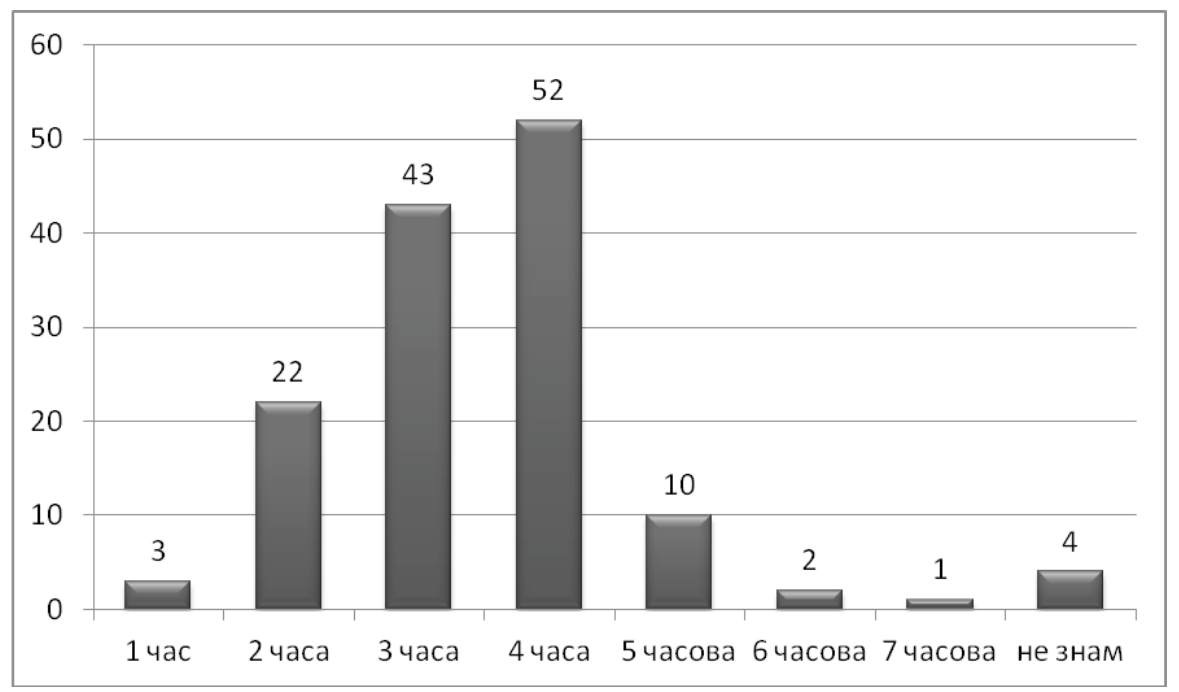

Број часова дневно у оквиру интензивног курса језика

Највећи број студената сматра да три или четири школска часа дневно представљају оптимално вријеме за учење језика.

Оваква временска организација омогућава предавачу:

- да започне и заврши једну језичку јединицу,

- да је развије на довољно репрезентативан, разумљив и пријемчив начин за потребе студената,

- да активира студенте и обезбиједи довољно простора за њихово језичко изражавање,

- да изврши текућу евалуацију претходно и ново наученог.

Са друге стране, студентима се омогућава:

- да научене језичке садржаје задрже у активном облику јер их понављају свакодневно,

- да активно учествују у реализацији часа јер је час довољно релаксиран,

- да развију навику за учење и употребу језика које намеће континуитет и динамика наставе. 


\section{7. Састав групе}

Када се говори о саставу групе, мисли се на три аспекта:

- језичко поријекло студената,

- степен (пред)знања језика и

- број студената.

2.7.1. Језичко поријекло студената, као што је напријед речено, утиче, како на планирање наставе, тако и на брзину постизања циља. Најлакше је организовати наставу за хомогену језичку групу чији је матерњи језик близак, сродан језику који се учи (нпр. језици унутар словенске породице језика). Поред сличне граматичке и препознатљиве лексичке структуре, што знатно олакшава успостављање прве комуникације, али и даљи ток трансфера знања новог језика, предавач има могућност да знатно брже напредује у реализацији наставе и да се задржи на „проблематичним мјестима“ типичним за контакте два језика. Наиме, сваки језик испољава своје битне карактеристике у процесу учења новог језика које могу бити на било ком или на сваком језичком нивоу и које утичу на појављивање типских грешака реметећи правилност језичког израза језика који се учи. Уочавајући ове наносе матерњег језика, предавач је у могућности да се довољно посвети њиховом кориговању пошто истим садржајем вјежби (истим поступцима) третира конкретан језички проблем код свих студената у групи.

Настава за студенте чији језици припадају различитим породицама у оквиру индоевропске групе језика олакшава предавачу организацију и реализацију наставе у том смислу што може да се ослони на заједничко поријекло језика (индоевропско), што значајно олакшава трансфер знања српског језика: фонетско писмо, структура ријечи и реченице, граматичке појаве у језику итд.

Организација наставе за студенте чији матерњи језик припада другачијој језичкој породици (азијски, семитски, афрички итд. језици) подразумијева знатно систематичнији приступ језику, свим његовим нивоима: фонетско-фонолошки, морфолошко-синтаксички и лексички систем се предају од самог почетка пошто се ниједан сегмент у 
језику не подразумијева нити га студент препознаје. Припадници сродних језика многе појаве и значења у језику могу да наслуте на основу сличности са матерњим језиком, али у случајевима различитих језичких породица сваку појаву у језику је потребно објаснити на задовољавајући начин како би се омогућила адекватна разумљивост.

Насупрот језички хомогеној групи, хетерогена језичка група захтијева од предавача знатно већу концентрисаност у раду и познавање (макар на теоретској основи) основних карактеристика, ако не сваког језика, макар језичке породице, како би помогао сваком студенту да препозна сличности и уочи разлике између свог матерњег и језика који учи.

2.7.2. Настава страног језика апсолутним почетницима у себи увијек носи одређену дозу изазова. Успостављање прве комуникације са студентима који у почетку не реагују ни на „Добар дан!“ и разговори са њима на крају одређеног наставног циклуса о различитим темама на, за њих, новом језику, ствара и код студената и код предавача осјећај поноса и задовољства. Међутим, успјех у трансферу језичког знања код апсолутних почетника умногоме зависи од способности предавача и његове дјелатности: избор метода и техника, правилно дозирање језичког садржаја, активирање свих студената на часу и развијање њихове интерне мотивације (о чему је већ било ријечи). На почетном нивоу учења студенти углавном зависе од предавача и његове способности и знања да им пренесе нове језичке садржаје, док на вишим нивоима знања студенти испољавају већу самосталност у свом раду и користе и друге изворе из којих црпе информације и додатна објашњења.

Међу методичарима наставе страних језика подијељено је мишљење о томе да ли је боље предавати језик апсолутним почетницима или студентима који већ имају предзнање о језику који уче. Наравно, све зависи од тога о којој врсти предзнања је ријеч. Опште је позната чињеница да студенти који са собом доносе одређено, ограничено знање стечено у кући или друштву (наши грађани у дијаспори) постижу знатно лошије резултате у процесу учења од оних који нису имали никакво предзнање. Узрок томе је што је то обично дијалекатски облик језика, граматички и лексички неправилан или 
архаичан и, пошто је стечен у раном узрасту, јако тешко се исправља у познијим годинама. Други разлог слабијем напредовању је што је студент са оваквим знањем ипак у стању да успостави комуникацију и да се вербално искаже, што знатно умањује његову мотивацију за даљим учењем и исправљањем грешака. Међутим, уколико се ради о коректном владању одговарајућег нивоа стандардног језика, наставак учења језика и усвајање виших нивоа знања, уз добро осмишљен програм и реално постављен циљ одвија се без проблема.

Најтежи облик наставе је у случајевима кад студенти у једној групи имају различит ниво (пред)знања, што и није тако риједак случај, без обзира на то да ли је у питању настава унутар студијског програма или курса језика. У том случају предавач треба да конципира наставу тако да омогући и једним и другим да усвоје нова или интерпретирају усвојена језичка знања: вербалним или писменим исказом на задату тему (у оквиру својих језичких могућности), комуникацијом са студентима уз употребу циљаних језичких средстава, замјеном улога гдје студенти са бољим знањем преносе информације осталим студентима, формирањем мјешовитих група са циљем рјешавања језичких задатака, већим оптерећењем студената са бољим знањем (давање примјера за језичка правила, проналажење другачијих рјешења, објашњење непознатих ријечи итд.). При томе, што није лако, треба водити рачуна да се довољно мотивишу и једни и други за заједнички рад, а то ће се постићи само тако што ће сви студенти бити подједнако укључени у наставни процес и уколико ће сви они након часа имати осјећај да су научили нешто ново.

2.7.3. Колики број студената је оптималан за наставу страног језика? Не постоји јединствено мишљење ни правило, постоје мишљења на основу различитих врста искустава. Обично техничке и организационе могућности диктирају одговор на то питање. Са методичког становишта, час је могуће организовати са једним студентом, са неколико студената и са групом студената (од 5 и више). У зависности од тога, прави се динамика и концепција часа.

Час са једним студентом, тзв. индивидуална настава (као што је напријед поменуто), претпоставља могућности и способности једног 
студента и према томе се прилагођава читав наставни процес. Предавач је у позицији да се потпуно посвети студенту, прилагоди темпо излагања његовим потребама и актуелизује интересовања студента кроз различите врсте вјежби, што може знатно да убрза остваривање предвиђеног циља. Са друге стране, могућности за интерактивни рад су сведене искључиво на дијалог између студента и предавача и самим тим прилично ограничене, недостатак других саговорника онемогућава студенту да своје знање позиционира у односу на знање других и, можда и најважнији недостатак ове врсте наставе, недостатак атмосфере која омогућава живост и природност језичке реакције.

Час са неколико студената ствара природније окружење за језичку акцију и реакцију: предавач је фокусиран на неколико студената и на основу тога може да прилагоди динамику наставе, студенти су растерећени континуиране пажње предавача, атмосфера на часу је опуштенија и самим тим природнија за актуелизацију језичког садржаја, језичке садржаје је могуће увјежбавати кроз различите типове вјежби чиме се повећава могућност евалуације и самоевалуације.

Час са групом студената (која често може да буде и прилично бројна) захтијева способност предавача да својим ауторитетом влада ситуацијом на часу, различитим способностима, захтјевима и могућностима студената. Предавач треба да пронађе адекватан начин интерпретације и евалуације језичког садржаја тако што ће дати могућност сваком студенту да се језички изрази или затражи додатна објашњења, што није нимало лако јер је за све то вријеме потребно одржати пажњу свих студената. То је могуће постићи формулацијом различитих типова вјежби и, прије свега, развијањем вербалне комуникације са и међу студентима. Оно што се добије као повратна информација од једног студента треба да послужи као тема о којој треба да дају мишљење и остали студенти. На тај начин се постиже задовољавајућа пажња на часу, а сви студенти су активни учесници у креирању и реализацији језичких активности.

Без обзира на то да ли је у питању један студент или већа или мања група студената, предавач треба да буде само навигатор часа, онај који бира адекватан садржај, методе и средства за његову 
реализацију и усмјерава језички израз студената у жељеном правцу. При томе, час треба да буде и простор и вријеме у коме ће страни студенти моћи да се искажу на функционалном српском језику, који ће моћи употријебити одмах по изласку из учионице.

\section{3. Завршне напомене}

Методички приступ настави страног језика, па тако и настави српског као страног језика, подразумијева комплексну врсту одговорности и организације од стране предавача. Прије свега, улога предавача је да изабере и интерпретира одговарајући језички садржај у складу са програмом и у оквиру предвиђеног времена, на начин који је разумљив свим студентима и који је довољно инспиративан да изазове језичку реакцију од стране студената, а као коначни циљ - овладавање студената језичким вјештинама одговарајућег нивоа. Да би коришћене методе и средства дали задовољавајући резултат, наставу је потребно конципирати у складу са одређеним захтјевима:

- дефинисати правила и обавезе студената током трајања наставе;

- инсистирати на активности свих студената на часу у складу са њиховим могућностима;

- уочавати, вредновати и поштовати мултикултуралне вриједности и различитости међу студентима;

- успоствити дијалог повјерења са и међу студентима;

- остварити комуникацију од првог часа;

- контролисати и усмјеравати комуникацију и друге језичке активности међу студентима;

- употребљавати функционални језик кроз актуелне теме.

\section{Литература}

Krajišnik, V. (2008). Multidisciplinarnost u izboru nastavnih sredstava u nastavi srpskog kao stranog jezika, U: Multidisciplinarnost u nastavi jezika i književnosti. Nikšić, 27-33.

Larsen-Freeman, D. (2000). Techniques and principles in language teaching. Oxford: Oxford University Press. 
Richards, J. and T. Rodgers (2001). Approaches and methods in language Teaching. Cambridge: Cambridge University Press.

Howatt, A. (1984). A history of English language teaching. Oxford: Oxford University Press.

Вилотијевић, М. (1999). Дидактика 1, 2, и 3. Београд: Научна књига, Учитељски факултет. Вучо, J. (2009). Како се учио језик. Београд: Филолошки факултет.

Дурбаба, О. (2011). Теорија и пракса учеа и наставе страних језика. Београд: Завод за уџбенике.

Кончаревић, К. (2004). Савремена настава руског језика. Београд: Славистичко друштво Србије.

Крајишник В. и В. Ломпар (2015). Искуства у онлајн настави српског као страног језика за ниво А1, Научни састанак слависта у Вукове дане, 44/3: 75-84.

Продановић, Т. и Р. Ничковић (1974). Дидактика. Београд: Завод за уџбенике и наставна средства

\title{
Vesna Krajišnik \\ University of Belgrade \\ Faculty of Philology
}

\section{SEVERAL QUESTIONS ON FOREIGN LANGUAGE TEACHING}

\begin{abstract}
Summary
This paper describes important elements of organizing Serbian as a foreign language teaching, in Serbian as well as in foreign language environment. Lesson typology and special characteristics of a foreign language class are pointed out, both from organizational and structural aspect. Paper does not offer solutions or rules, but illustrates possibilities which emerged from long term of experience in foreign language classroom. Purpose of this paper is to help those who are entering Serbian as a foreign language classroom for the first time, in Serbia and abroad.
\end{abstract}

Key words: methods in teaching foreign language, Serbian as a foreign language, lecturing classes, organisation of classes 